Original Research Article

\title{
Evaluation of Cardioprotective activity of Asparagus racemosus against Doxorubicin induced cardiotoxicity in albino rats: an experimental study
}

\author{
Pinki Vishwakarma, Manisha Chatterjee*, Monica Sharma, Manish Saini, Rajkumar Goel, \\ K. K. Saxena
}

Department of Pharmacology, Lala Lajpai Rai Memorial Medical College Meerut, Meerut, Uttar Pradesh, India

Received: 15 April 2019 Accepted: 10 June 2019

*Correspondence to: Dr. Manisha Chatterjee, Email: manishachatterjee1988@ gmail.com

Copyright: () the author(s), publisher and licensee Medip Academy. This is an openaccess article distributed under the terms of the Creative Commons Attribution NonCommercial License, which permits unrestricted noncommercial use, distribution, and reproduction in any medium, provided the original work is properly cited.

\begin{abstract}
Background: Cardiotoxicity is one of the most feared side effects of anticancer agents like Doxorubicin. Asparagus racemosus is a widely used medicinal plant in Indian system of medicine known for its antioxidant activity. In certain studies ethanol extract of Asparagus racemosus has shown to possess cardioprotective activity in experimental animals while in some other studies cardioprotective potential of Asparagus racemosus has not been demonstrated. Therefore, due to the controversial action, the present study was designed to explore the cardioprotective effect of aqueous effect of Asparagus racemosus against doxorubicin induced cardiotoxity.

Methods: Following approval from Institutional Animal Ethics Committee of L.L.R.M Medical College registered under CPCSEA, India, this study was conducted in which 30 rats were randomized into five groups of six rats each. Group I received $2 \mathrm{ml} / \mathrm{kg} \mathrm{b}$.w. normal saline p.o for 21 days, group II apart from receiving pellet diet and normal saline for 21 days were treated with Doxorubicin in a single dose of $20 \mathrm{mg} / \mathrm{kg}$ intraperitoneally on the $21^{\text {st }}$ day, group III and group IV received aqueous extract of Asparagus racemosus in doses of $250 \mathrm{mg} / \mathrm{kg} /$ day and $500 \mathrm{mg} / \mathrm{kg} /$ day respectively p.o. for 21 days followed by administration of Doxorubicin $\left(20 \mathrm{mg} / \mathrm{kg}\right.$ i.p.) on the $21^{\text {st }}$ day, Group V received Carvedilol in doses of $30 \mathrm{mg} / \mathrm{kg} /$ day p.o. for 21 days followed by administration of Doxorubicin (20mg/kg i.p) on the $21^{\text {st }}$ day. Then they were anaesthetized and blood sample was collected from abdominal aorta for performing blood test i.e. Creatinine kinase MB fraction (CK-MB), Lactate dehydrogenase (LDH), Serum glutamate oxaloacetate transaminase (SGOT), Serum glutamate pyruvate transaminase (SGPT). After blood collection the animals were sacrificed and heart was dissected out for histopathological study. The data obtained was organized and analysed by suitable statistical methods i.e. ANOVA followed by Post Hoc test.

Results: CK-MB, LDH, SGOT and SGPT levels were found to be significantly raised $(\mathrm{p}<0.001)$ in Doxorubicin treated group. Asparagus racemosus pretreated groups exhibited significant limitation $(\mathrm{p}<0.001)$ in rise in levels of CK-MB,LDH,SGOT and SGPT levels in a dose dependent manner following Doxorubicin administration which were comparable to the group treated with the standard cardioprotective drug Carvedilol. Histopathological changes further corroborated cardioprotective potential of Asparagus racemosus.

Conclusions: The present study concluded that aqueous extract of Asparagus racemosus possess cardioprotective potential against Doxorubicin induced cardiotoxicity.
\end{abstract}

Keywords: Asparagus racemosus, Cardiotoxicity, Carvedilol, Doxorubicin
INTRODUCTION
Cardiovascular diseases (CVD) constitute the leading cause of mortality and morbidity globally. According to the World Health Organization (WHO), an estimated 17.7 
million people died from CVDs in 2017, representing $31 \%$ of all global deaths. With the current trends, the top cause of disability adjusted life years (DALYs) lost in 2020 is most likely going to be ischemic heart disease. ${ }^{1}$

The contributing factors for cardiomyopathy include long term high blood pressure, heart valve problems, metabolic disorders, nutritional deficiencies, excessive alcohol consumption, and use of some chemotherapeutic drugs like doxorubicin to treat cancer, certain infections, amyloidosis and others.

Cardiotoxicity is a general term used to define "toxicity that affects the heart". ${ }^{2}$ It is the occurrence of electrophysiological dysfunction and/or muscle damage in the heart. Cardiotoxicity includes a wide range of cardiac effects from small changes in blood pressure and arrhythmias to cardiomyopathy.

Cardiotoxicity can be of idiopathic origin or it can be drug induced. Drugs like methamphetamine, isoproterenol, cyclosporine A, minoxidil, 5-flurouracil, cyclophosphamide, anthracycline class of chemotherapeutic agents like daunorubicin, epirubicin, doxorubicin and idrarubicin, antipsychotic drugs like sertindole and thioridazine are known to cause cardiotoxicity by various mechanisms. ${ }^{3}$

Cardiotoxicity is one of the most feared side effects of anticancer agents so much so that the gain in life expectancy due to anticancer therapy might be associated with heart failure (HF), myocardial ischemia, arrhythmias, hypertension, thromboembolism etc. ${ }^{4}$

Cardioprotective drugs are important in the treatment of patients at risk for or with documented cardiovascular disease. There are various classes of cardioprotective drugs like timolol, metoprolol, propranolol, bisoprolol which are beta blockers, carvedilol which blocks $\beta 1, \beta 2$ and $\alpha 1$ receptors, remipril, enalapril, lisinopril which are angiotensin converting enzyme inhibitors, losartan, telmisartan which are angiotensin receptor blockers. Apart from these properties of drugs, the cardioprotective effects are also attributed to the antioxidant properties of these drugs. These drugs prevent smooth muscle mitogenesis and cardiac remodelling. ${ }^{5}$

However certain side effects are observed with the use of these drugs which include dizziness, unusual tiredness, low blood pressure, and allergic reactions with carvedilol, dry cough, dysgeusia and angioedema with angiotensin converting enzyme inhibitors, drowsiness, fatigue, dyslipidaemia, cold hands and feet and bradycardia with beta blockers.

Indigenous drugs are generally safe and are free from side effects. Several indigenous plants have shown cardioprotective potential due to their antioxidant properties. The present study has been undertaken to screen the cardioprotective activity of the indigenous plant Asparagus racemosus due to its antioxidant properties. ${ }^{6}$

Asparagus racemosus, commonly known as Shatavri belongs to the family Asparagaceae. The root extracts of Asparagus racemosus are often used to treat women's health disorder. They are also advocated for use in leucorrhoea and menorrhagia. ${ }^{7}$ It also demonstrates antitussive, antibacterial antihepatotoxic, immunomodulatory antioxidant, antidepressant and anti- inflammatory properties. ${ }^{8-17}$ Though extract of Asparagus racemosus roots has several therapeutic properties, it has not been tested for it's cardioprotective activity against doxorubicin induced cardiotoxicity.

Due to paucity of scientific literature exploring the cardioprotective potential of Asparagus racemosus, the present study is planned to evaluate the preventive effect of Asparagus racemosus on Doxorubicin induced cardiotoxicity in albino rats.

\section{METHODS}

\section{Experimental animals}

Healthy albino wistar rats of either sex weighing 150-200g were procured from the rat rearing unit of the Central Animal House of the institute. The selected animals were grouped and housed in polypropylene cages in CPCSEA approved animal house of LLRM Medical College and maintained under standard laboratory conditions of alternating periods of light and darkness of $12 \mathrm{hr}$ each and under controlled conditions of temperature $\left(25 \pm 2^{\circ} \mathrm{C}\right)$ and relative humidity ( 45 to $55 \%$ ) with free access to standard rat pellet diet and tap water ad libitum. After one week of acclimatization, the animals were considered suitable for study. Pregnant female rats were not included in the study. The study was approved by the IAEC (Approval no. IAEC/2017/2 dated 16/9/17).

\section{Method of preparation of extract}

\section{Asparagus racemosus}

To prepare asparagus extract, the roots were completely cleaned and dried in the laboratory as powder form. The resultant powder was extracted with $96 \%$ ethyl alcohol. The mixture was stirred in rotodoxy device for 24 hours at room temperature to obtain a uniform solution. The solution was filtered and dried for 48 hours at ambient condition to obtain a solid extract with no alcohol. When needed the extract was dissolved in distilled water and was used in the study. ${ }^{18}$

\section{Drugs and chemicals}

Doxorubicin hydrochloride (Zubidox) was purchased from Adley formulations Pvt. Ltd. India. Carvedilol (Carca) was purchased from Intas Pharmaceutical Pvt.Ltd. India. 
SGOT and SGPT test assay kit were procured from ELI Tech clinical system, France.

\section{Experimental study design}

The animals were randomly divided into five groups of six animals each. The groups were described as:

- Group I: Control group was given $0.9 \% \mathrm{NaCl}$ solution in a single oral dose of $2 \mathrm{ml} / \mathrm{kg}$ b.w for 21 days.

- Group II: In addition to pellet diet and tap water ad libitum the animals of this group were treated with doxorubicin in a single dose of $20 \mathrm{mg} / \mathrm{kg}$ intraperitoneally on $21^{\text {st }}$ day.

- Group III and Group IV: These groups were treated with aqueous extract of Asparagus racemosus (AEAR) in two selected graded doses for 21 days respectively followed by administration of Doxorubicin (20 mg/kg i.p.) as in group II.

- Group V: This group was treated with Carvedilol (standard cardioprotective drug) $30 \mathrm{mg} / \mathrm{kg}$ per orally for 21 days followed by administration of Doxorubicin (20 mg/kg i.p.) as in group-II.

Animals of all the groups were fasted for 48 hours (during which tap water remained freely available) following administration of Doxorubicin. Then they were sacrificed using Ketamine $(75 \mathrm{mg} / \mathrm{kg})$ and Diazepam $(10 \mathrm{mg} / \mathrm{kg})$ anesthesia, given intraperitoneally. Blood sample was collected from abdominal aorta for performing blood test i.e. CK, LDH, SGOT, SGPT. After blood collection the animals were sacrificed, and heart was dissected out for histopathological study.

The data thus obtained was appropriately organized and analyzed by suitable statistical methods i.e. ANOVA.

\section{Estimation of biochemical parameters}

The collected blood sample, after a standing period of half an hour, was centrifuged in Remi R-8 centrifuge at about $2500 \mathrm{rpm}$ for 10 minutes. The serum so separated was used for the following tests:

- Creatinine kinase MB fraction (CK-MB)

- $\quad$ Lactate dehydrogenase (LDH)

- Serum glutamate oxaloacetate transaminase (SGOT)

- Serum glutamate pyruvate transaminase (SGPT)

\section{RESULTS}

\section{CK-MB}

The mean CK-MB level in normal saline treated group was $0.85 \pm 0.01 \mathrm{IU} / \mathrm{L}$. It was found to be significantly increased $(\mathrm{p}<0.001)$ to $12.55 \pm 0.08 \mathrm{IU} / \mathrm{L}$ following Doxorubicin administration $(20 \mathrm{mg} / \mathrm{kg}$, i.p). Pretreatment with standard drug Carvedilol (30 mg/kg p.o), significantly ( $\mathrm{p}<0.001)$ limited the rise in CK-MB levels to $3.5 \pm 0.17$ after administration of Doxorubicin (20 mg/kg, i.p) (Table 1).
Asparagus racemosus extract revealed dose dependent limitation of rise in CK-MB levels after Doxorubicin administration $(20 \mathrm{mg} / \mathrm{kg}$, i.p). Although the dose of 250 $\mathrm{mg} / \mathrm{kg}$ per orally for 21 days showed a significant limitation $(p<0.05)$ of CK-MB rise $(10.16 \pm 0.11$ IU/L) when compared to Doxorubicin treated group, but it did not match the efficacy of Carvedilol treated group. When administered in higher dose of $500 \mathrm{mg} / \mathrm{kg}$ per orally for 21 days, the Asparagus racemosus extract had better efficacy in limiting the CK-MB rise to $9.76 \pm 0.14 \mathrm{IU} / \mathrm{L}$ following administration of Doxorubicin $(20 \mathrm{mg} / \mathrm{kg}$, i.p), which was found to be statistically significant $(\mathrm{p}<0.001)$ (Table 1).

Table 1: Effect of Carvedilol and Asparagus racemosus in their respective doses on Doxorubicin induced changes in serum CK-MB (IU/L) $(\operatorname{mean} \pm \mathrm{SE})(\mathrm{n}=6)$.

\begin{tabular}{|l|l|l|}
\hline Group & $\begin{array}{l}\text { Treatment } \\
(\text { p.o } \mathrm{mg} / \mathrm{kg})\end{array}$ & $\begin{array}{l}\text { CK-MB (IU/L) } \\
(\text { mean } \pm \text { SE) }\end{array}$ \\
\hline I & $\begin{array}{l}\text { Normal Saline } \\
(2 \mathrm{ml} / \mathrm{kg}, \mathrm{p} . \mathrm{o})\end{array}$ & $0.85 \pm 0.01$ \\
\hline II & $\begin{array}{l}\text { Doxorubicin } \\
(20 \mathrm{mg} / \mathrm{kg}, \mathrm{i} . \mathrm{p})\end{array}$ & $12.55 \pm 0.08^{\wedge}$ \\
\hline III & Carvedilol (30) & $3.5 \pm 0.17^{\Omega}$ \\
\hline IV & $\begin{array}{l}\text { Asparagus racemosus } \\
(250)\end{array}$ & $10.16 \pm 0.11^{*}$ \\
\hline V & $\begin{array}{l}\text { Asparagus racemosus } \\
(500)\end{array}$ & $4.45 \pm 0.33^{\Omega}$ \\
\hline
\end{tabular}

${ }^{\wedge} \mathrm{p}<0.001$ as compared to normal saline treated group, ${ }^{\Omega} \mathrm{p}<0.001$ as compared to DOX treated group, ${ }^{*} \mathrm{p}<0.05$ as compared to DOX treated group.

\section{LDH}

The mean LDH level in normal saline treated group was $249.16 \pm 5.38 \mathrm{IU} / \mathrm{L}$. It was found to be significantly increased $(\mathrm{p}<0.001)$ to $1337 \pm 20.75 \mathrm{IU} / \mathrm{L}$ following administration of Doxorubicin (20mg/kg, i.p) (Table 2).

Table 2: Effect of Carvedilol and Asparagus racemosus in their respective doses on Doxorubicin induced changes in serum LDH (IU/L) $($ mean \pm SE) $(n=6)$.

\begin{tabular}{|l|l|l|}
\hline Group & $\begin{array}{l}\text { Treatment } \\
(\mathbf{p} .0 \mathrm{mg} / \mathrm{kg})\end{array}$ & $\begin{array}{l}\text { LDH (IU/L) } \\
(\text { mean } \pm \text { SE) }\end{array}$ \\
\hline I & $\begin{array}{l}\text { Normal Saline } \\
(2 \mathrm{ml} / \mathrm{kg}, \mathrm{p} . \mathrm{o})\end{array}$ & $249.16 \pm 5.38$ \\
\hline II & $\begin{array}{l}\text { Doxorubicin } \\
(20 \mathrm{mg} / \mathrm{kg}, \mathrm{i} . \mathrm{p})\end{array}$ & $1337 \pm 20.75^{\wedge}$ \\
\hline III & Carvedilol (30) & $508.16 \pm 7.78^{\Omega}$ \\
\hline IV & $\begin{array}{l}\text { Asparagus racemosus } \\
(250)\end{array}$ & $778 \pm 32.03^{*}$ \\
\hline V & $\begin{array}{l}\text { Asparagus racemosus } \\
(500)\end{array}$ & $576.66 \pm 5.19^{\Omega}$ \\
\hline
\end{tabular}

${ }^{\wedge} \mathrm{p}<0.001$ as compared to normal saline treated group, ${ }^{\Omega} \mathrm{p}<0.001$ as compared to DOX treated group, ${ }^{*} \mathrm{p}<0.05$ as compared to DOX treated group. 
Pretreatment with standard drug Carvedilol (30 $\mathrm{mg} / \mathrm{kg}, \mathrm{p} . \mathrm{o})$, significantly $(\mathrm{p}<0.001)$ limited the rise in LDH levels to $508.16 \pm 7.78$ IU/L following administration of Doxorubicin.

Asparagus racemosus explored dose dependent limitation of $\mathrm{LDH}$ rise following Doxorubicin administration. Although the dose of $250 \mathrm{mg} / \mathrm{kg}$ per orally for 21 days demonstrated a significant limitation $(\mathrm{p}<0.05)$ of $\mathrm{LDH}$ rise $(778 \pm 32.03 \mathrm{IU} / \mathrm{L})$ when compared to Doxorubicin treated group $(20 \mathrm{mg} / \mathrm{kg}$, i.p),but it did not match the efficacy of Carvedilol treated group. With the dose of $500 \mathrm{mg} / \mathrm{kg}$ per orally for 21 days, the Asparagus racemosus extract had much better efficacy in limiting the $\mathrm{LDH}$ rise to $576.66 \pm 5.19$ IU/L following administration of Doxorubicin $(20 \mathrm{mg} / \mathrm{kg}$, i.p), which was found to be statistically significant $(\mathrm{p}<0.001)$ (Table 2$)$.

\section{SGOT}

The mean SGOT level in normal saline treated group was $34.25 \pm 0.62 \mathrm{IU} / \mathrm{L}$. It was found to be significantly increased ( $\mathrm{p}<0.001)$ to $218.66 \pm 9.18 \mathrm{IU} / \mathrm{L}$ following administration of Doxorubicin $(20 \mathrm{mg} / \mathrm{kg}$, i.p) (Table 3$)$.

Table 3: Effect of Carvedilol and Asparagus racemosus in their respective doses on Doxorubicin induced changes in serum SGOT $($ IU/L) (mean \pm SE) $(\mathrm{n}=6)$.

\begin{tabular}{|lll|}
\hline Group & $\begin{array}{l}\text { Treatment (p.o } \\
\text { mg/kg) }\end{array}$ & $\begin{array}{l}\text { SGOT (IU/L) } \\
(\text { mean } \pm \text { SE) }\end{array}$ \\
\hline I & $\begin{array}{l}\text { Normal Saline } \\
(2 \mathrm{ml} / \mathrm{kg}, \mathrm{p} . \mathrm{o})\end{array}$ & $34.25 \pm 0.62$ \\
\hline II & $\begin{array}{l}\text { Doxorubicin } \\
(20 \mathrm{mg} / \mathrm{kg}, \mathrm{i} . \mathrm{p})\end{array}$ & $218.66 \pm 9.18^{\wedge}$ \\
\hline III & Carvedilol (30) & $116 \pm 1.58^{\Omega}$ \\
\hline IV & $\begin{array}{l}\text { Asparagus racemosus } \\
(250)\end{array}$ & $159.5 \pm 4.84^{*}$ \\
\hline V & $\begin{array}{l}\text { Asparagus racemosus } \\
\text { (500) }\end{array}$ & $124.66 \pm 1.35^{\Omega}$ \\
\hline
\end{tabular}

${ }^{\wedge} \mathrm{p}<0.001$ as compared to normal saline treated group, ${ }^{\Omega} \mathrm{p}<0.001$ as compared to DOX treated group, ${ }^{*} \mathrm{p}<0.05$ as compared to DOX treated group.

Pretreatment with standard drug Carvedilol (30mg/kg, p.o) significantly $(\mathrm{p}<0.001)$ limited the rise in SGOT levels after Doxorubicin administration (20 mg/kg, i.p.) to $116 \pm 1.58 \mathrm{IU} / \mathrm{L}$.

Asparagus racemosus extract explored dose dependent limitation of rise in SGOT levels after Doxorubicin administration. Although the dose of $250 \mathrm{mg} / \mathrm{kg}$ per orally for 21 days demonstrated a significant limitation $(\mathrm{p}<0.001)$ of SGOT rise $(159.5 \pm 4.84 \mathrm{IU} / \mathrm{L})$ when compared to Doxorubicin treated group $(20 \mathrm{mg} / \mathrm{kg}$, i.p.) but it did not match the efficacy of Carvedilol treated group $(\mathrm{p}<0.05)$. However, the dose of $500 \mathrm{mg} / \mathrm{kg}$ per orally for 21 days, the Asparagus racemosus extract showed much better efficacy, in limiting the SGOT rise to $124.66 \pm 1.35 \mathrm{IU} / \mathrm{L}$ following administration of Doxorubicin (20mg/kg, i.p), which was found to be statistically significant $(\mathrm{p}<0.001)$ (Table 3).

\section{SGPT}

The mean SGPT level in normal saline treated group was $37.08 \pm 0.32 \mathrm{IU} / \mathrm{L}$. It was found to be significantly increased $(\mathrm{p}<0.001)$ to $172.33 \pm 2.10 \mathrm{IU} / \mathrm{L}$ following administration of Doxorubicin (20 mg/kg, i.p) (Table 4).

Table 4: Effect of Carvedilol and Asparagus racemosus in their respective doses on Doxorubicin induced changes in serum SGPT $(I U / L)($ mean \pm SE) $(n=6)$.

Table 4: Effect of Carvedilol and Asparagus racemosus in their respective doses on Doxorubicin induced changes in serum SGPT (IU/L) $($ mean \pm SE) $(n=6)$.

\begin{tabular}{|lll|}
\hline Group & \multicolumn{1}{|c|}{$\begin{array}{l}\text { Treatment } \\
(\mathbf{p} .0 \mathrm{mg} / \mathrm{kg})\end{array}$} & $\begin{array}{c}\text { SGPT (IU/L) } \\
(\text { mean } \pm \text { SE) }\end{array}$ \\
\hline I & $\begin{array}{l}\text { Normal Saline }(2 \\
\text { ml/kg.p.o) }\end{array}$ & $37.08 \pm 0.32$ \\
\hline II & $\begin{array}{l}\text { Doxorubicin }(20 \\
\text { mg/kg,i.p) }\end{array}$ & $172.33 \pm 2.10^{\wedge}$ \\
\hline III & Carvedilol (30) & $76.66 \pm 1.2^{\Omega}$ \\
\hline IV & $\begin{array}{l}\text { Asparagus racemosus } \\
\text { (250) }\end{array}$ & $93.16 \pm 2.35^{*}$ \\
\hline V & $\begin{array}{l}\text { Asparagus racemosus } \\
\text { (500) }\end{array}$ & $81.33 \pm 1.62^{\Omega}$ \\
\hline
\end{tabular}

${ }^{\wedge} \mathrm{p}<0.001$ as compared to normal saline treated group, ${ }^{\Omega} \mathrm{p}<0.001$ as compared to DOX treated group, ${ }^{*} \mathrm{p}<0.05$ as compared to DOX treated group.

Pretreatment with standard drug Carvedilol (30mg/kg p.o), significantly $(\mathrm{p}<0.001)$ limited the rise in SGPT levels to $76.66 \pm 1.2 \mathrm{IU} / \mathrm{L}$ following administration of Doxorubicin (20mg/kg, i.p.).

Asparagus racemosus extract explored dose dependent limitation of SGPT rise after Doxorubicin administration. Although the dose of $250 \mathrm{mg} / \mathrm{kg}$ per orally for 21 days showed a significant limitation $(\mathrm{p}<0.05)$ of SGPT rise $(93.16 \pm 2.35 \mathrm{IU} / \mathrm{L})$ when compared to Doxorubicin treated group $(20 \mathrm{mg} / \mathrm{kg}$, i.p. $)$, but it did not match the efficacy of Carvedilol treated group. However in the dose of 500 $\mathrm{mg} / \mathrm{kg}$ per orally for 21 days Asparagus racemosus extract showed much better efficacy in limiting the SGPT rise to $81.33 \pm 1.62 \mathrm{IU} / \mathrm{L}$ following administration of Doxorubicin $(20 \mathrm{mg} / \mathrm{kg}$, i.p.), which was found to be statistically significant $(\mathrm{p}<0.001)$ (Table 4$)$.

\section{Histopathological changes}

The histopathological sections of heart of rats of saline treated group showed normal striated muscles, clearly visible striations and well aligned oval flattened nuclei (Figure 1). 
DOX administration resulted in intramuscular haemorrhage, oedema, fragmentation of muscle fibres, vacoulation and infiltration with inflammatory cells (Figure 2).

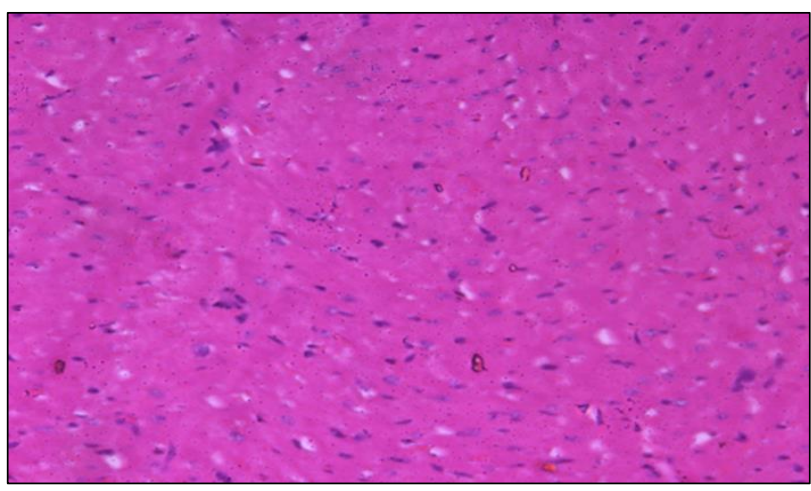

Figure 1: Light micrographs (40X) of section from heart tissue stained with haematoxylin and eosin showing normal histological architecture of heart in rats treated with normal saline $(2 \mathrm{ml} / 100 \mathrm{~g} /$ day p.o $)$.

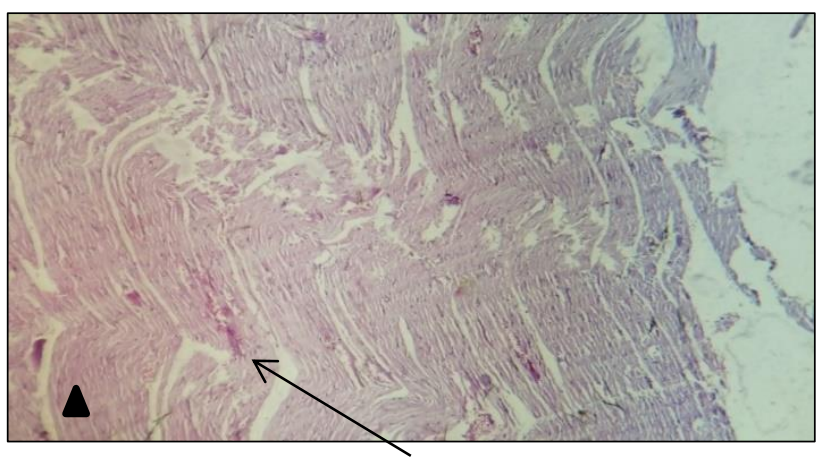

Figure 2: Light micrographs (40X) of section from heart tissue stained with haematoxylin and eosin showing intense inflammation and haemorrhage

(arrowhead), cytoplasmic esosinophilia and degeneration of muscle fibres (arrow) in rats treated with DOX (20mg/kg i.p single dose).

Degree of protection with Asparagus racemosus against Doxorubicin induced cardiotoxicity was evident clearly on histopathological examination of cardiac tissue.

Rats treated with Asparagus racemosus $(250 \mathrm{mg} / \mathrm{kg} / \mathrm{day}$ p.o+DOX $20 \mathrm{mg} / \mathrm{kg}$ i.p single dose) for 21 days showed slight derangement of muscle fibres, mild intramuscular hemmorhage and mild inflammation.

In rats treated with Asparagus racemosus $(500 \mathrm{mg} / \mathrm{kg} /$ day p.o+DOX $20 \mathrm{mg} / \mathrm{kg}$ i.p single dose) for 21 days showed preservation of normal cardiac muscle morphology with no inflammation which was similar to that seen in Carvedilol treated group (Figure 3).

In rats treated with Carvedilol (30 mg/kg/day p.o+Doxorubicin $20 \mathrm{mg} / \mathrm{kg}$ i.p single dose) for 21 days showed parallel arrangement of muscle fibres with peripherally located normal nuclei (arrow) as seen in Figure 4.

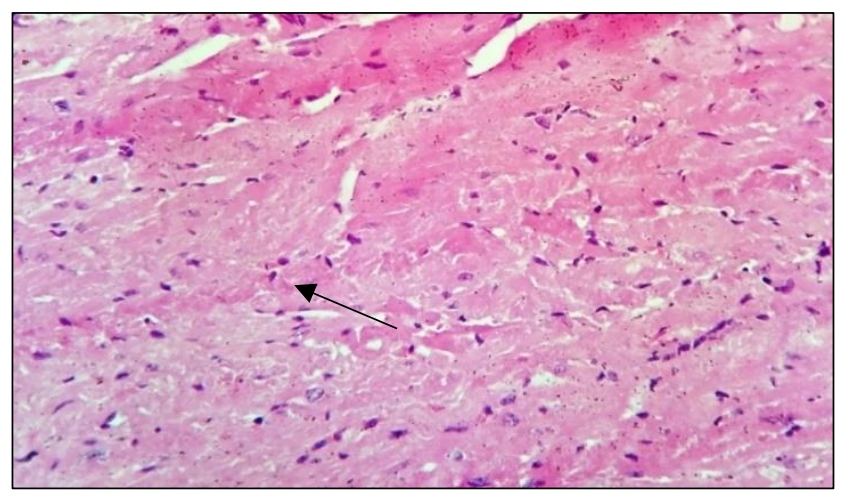

Figure 3: Light micrographs (40X) of section from heart tissue stained with haematoxylin and eosin showing slight derangement of muscle fibres (arrow) and mild inflammation (arrow head) in rats treated with Asparagus racemosus $(500 \mathrm{mg} / \mathrm{kg} / \mathrm{day}$ p.o+Doxorubicin $20 \mathrm{mg} / \mathrm{kg}$ i.p.) single dose) for 21 days.

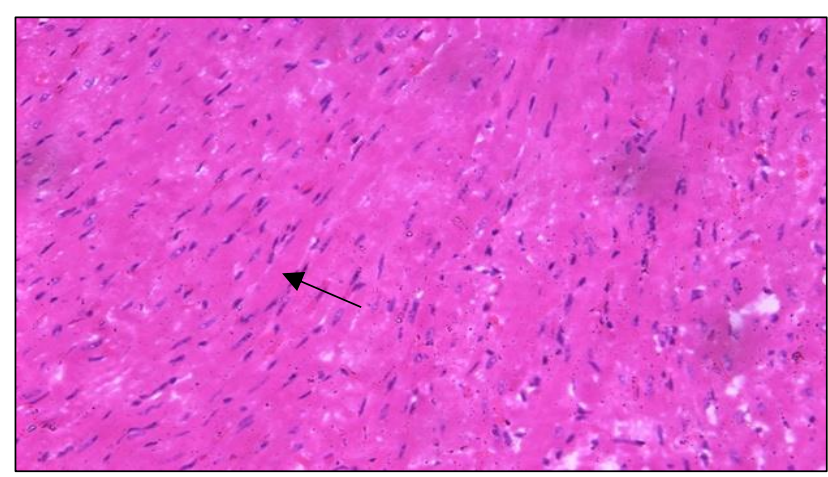

Figure 4: Light micrographs (40X)of section from heart tissue stained with haematoxylin and eosin showing parallel arrangement of muscle fibres with peripherally located normal nuclei (arrow) seen in rats treated with Carvedilol $(30 \mathrm{mg} / \mathrm{kg} / \mathrm{day}$ p.o + Doxorubicin 20mg/kg i.p single dose) for 21 days.

\section{DISCUSSION}

Doxorubicin (DOX), a drug belonging to anthracycline group, is a highly effective antitumor drug but its usefulness is now very much limited due to potentially fatal cardiotoxic effects by this drug. ${ }^{19-20}$ There are multiple proposed mechanisms of doxorubicin-induced cardiotoxicity. However, the most widely cited and accepted mechanism is the formation of reactive oxygen species (ROS) leading to oxidative stress. This results in impaired mitochondrial function, cellular membrane damage and cytotoxicity. ${ }^{21}$ The rat model of doxorubicin induced cardiotoxicity has been widely used as a standard method to evaluate cardioprotective drugs and to study myocardial consequences of ischemic disorders. ${ }^{22} \mathrm{DOX}$ in a single dose of $20 \mathrm{mg} / \mathrm{kg}$ intraperitoneally has been used 
to induce cardiotoxicity in experimental studies also. ${ }^{23}$ The therapeutic actions of most medicinal plants are related to their antioxidant properties which, in turn, could be ascribed to their antioxidant phytochemicals present in them. ${ }^{24}$ Asparagus racemosus is a good source of polyphenols (kaempferol and rutin) and flavonoids. It also possesses racemosol, racemofuran, sitosterol, diosgenin, quercetin and glucourbnides. ${ }^{25}$ Myocardium contains an abundant amount of diagnostic marker enzymes for cardiotoxicity and once metabolically damaged, it releases its intracellular contents into the extracellular fluid so the serum levels of these marker enzymes (CK-MB, cLDH, cSGOT and SGPT) reflect the alterations in membrane integrity and/or permeability. ${ }^{26-27}$ In the present study, serum Creatinine phosphokinase-MB (CKMB), Lactate dehydrogenase (LDH), Serum glutamate oxaloacetate transaminase (SGOT) and Serum glutamate pyruvate transaminase (SGPT) were used as biochemical markers for cardiac injury. Results of the present study indicate that administration of DOX $(20 \mathrm{mg} / \mathrm{kg}$ i.p) elevated the serum levels of CKMB, LDH, SGOT and SGPT signifying myocardial damage and this rise of serum markers was found to be statistically significant in our study also. It was interesting to note that CK-MB levels were significantly low in the Asparagus racemosus pretreated rats (Table 1). Further, Asparagus racemosus in the doses of $500 \mathrm{mg} / \mathrm{kg}$ conferred more cardioprotection than in the doses of 250 $\mathrm{mg} / \mathrm{kg}$. In the present study, a significant rise in the LDH levels was observed in rats treated with DOX after 48 hour of the treatment. Asparagus racemosus caused significant reduction in the elevated levels of $\mathrm{LDH}$ indicating the reduction in the severity of cardiotoxicity (Table 2 ).

Ravichandra et al, reported rise in levels of SGOT and SGPT after the infarction of the myocardium. SGOT and SGPT are nonspecific indicators but are known quantitative indices of compromised cell integrity induced by DOX. ${ }^{28}$ DOX treatment elevated these enzyme levels in serum to a significant extent and pretreatment with Asparagus racemosus doses significantly reduced the elevated levels of SGOT and SGPT. The results of the serum markers correlated with the histopathological observations in the myocardial tissue of animals treated with either DOX or test drugs or normal saline (Table 3, 4 ). The myocardial tissue of saline treated rats illustrated clear integrity of the myocardial cell membrane and absence of any inflammatory cell infiltration (Figure 1). DOX injected rats showed separation of cardiac muscle fibers and infiltration of inflammatory cells (Figure 2). The reduced inflammatory cell infiltration and normal cardiac muscle fibre architecture in Asparagus racemosus treated rats further confirmed the cardio protective effect (Figure 3). In present study doxorubicin induced rise of serum markers was significantly decreased by the pretreatment of Asparagus racemosus (Tables 1 to 4 ). The results of present study demonstrated that Asparagus racemosus provides cardio protection against doxorubicin induced cardiotoxicity. This cardioprotective effect of Asparagus racemosus can be attributed to their antioxidant phytochemicals like polyphenols and flavonoids present in it. ${ }^{29}$ Asparagus racemosus exhibits excellent antioxidant activity in its methanol, ethanol and aqueous extracts. ${ }^{30}$ However, the antioxidant activity was found more in alcoholic extracts as compared to aqueous extract in a study by Premanath and Lakshmi Devi 2010 as the active principles were supposed to be mainly filtered out in alcoholic extract. Further studies of longer duration are needed to explore the therapeutic efficacy of Asparagus racemosus as cardioprotective drug. ${ }^{31}$

\section{CONCLUSION}

In the present study it was found that pretreatment with aqueous extracts of Asparagus racemosus significantly reduced the Doxorubicin induced damage to rat myocardium without any harmful side effects. This cardioprotective potential of Asparagus racemosus might be attributed to the synergistic effect due to the antioxidant properties of the chemical compounds like polyphenols and flavonoids present in them. Based on these observations, it can be proposed that Asparagus racemosus may provide a therapeutic option against drug induced cardiotoxicity. The present study also carries a scope for further assessment of Asparagus racemosus with its hydroalcoholic extract, other dose levels and extended test durations, other biochemical parameters, isolation and structure determination of the cardioprotective principles and a detailed explanation of the mechanism of action. Further an elaborate investigation to explore the pharmacokinetic profile may lead to better efficacy and potency of Asparagus racemosus. An extended study using large number of animals is required so that substantial data can be generated for facilitating further evaluation of these agents through clinical trials. Further molecular level of investigation could be done using different animal models and other biochemical parameters to elaborate the possible mechanism of action of Asparagus racemosus.

\section{Funding: No funding sources}

Conflict of interest: None declared

Ethical approval: The study was approved by the Institutional Ethics Committee (Approval no. IAEC/2017/2 dated 16/9/17)

\section{REFERENCES}

1. Rosamond W, Flegal K, Furie K, Go A, Greenlund K, Haase N, et al. Heart disease and stroke statistics-2017 update: a report from the American Heart Assosiation Statistics Committee and Stroke Statistics subcommittee, Circulation. 2017;117(5):25-146.

2. Ewer MS, Vooletich MT, Durand JB. Reversibility of trastuzumab-related cardiotoxicity: New insights based on clinical course and response to medical treatment. J Clin Oncol. 2005;23(31):7820-6.

3. Singh G, Sing AT, Abraham A, Bhat B, Mukherjee A, Verma R, et al. Protective effects of Terminalia arjuna against doxorubicin induced cardiotoxicity. J Ethanopharmacol. 2008;117(1):123-9. 
4. Von Hoff DD, Layard MW, Basa P, Davis HL Jr, Von Hoff AL, Rozencweig M, et al. Risk factors for doxorubicin-induced congestive heart failure. Ann Intern Med. 1979;91(5):710-7.

5. Kalay N, Basar E, Ozdogru I, Er O, Cetinkaya Y, Dogan A. Protective effects of carvedilol against anthracycline-induced cardiomyopathy. J Am Coll Cardiol. 2006;48(11):2258-62.

6. Varshney P, Vishwakarma P, Sharma M, Saini M, Bhatt S, Singh G, et al. Cardioprotective effect of Solanum nigrum against doxorubicin induced cardiotoxicity-an experimental study. Int J Basic Clin Pharmacol. 2016;5(3):748-50.

7. Kalay N, Basar E, Ozdogru I, Er O, Cetinkaya Y, Dogan A. Protective effects of carvedilol against anthracycline-induced cardiomyopathy. J Am Coll Cardiol. 2006;48(11):2258-62.

8. Matsui H, Morishima I, Numaguchi Y, Toki Y, Okumura K, Hayakawa T. Protective effects of carvedilol against doxorubicin-induced cardiomyopathy. Life Sci. 1999;65(12):1265-74.

9. Sharma K, Bhatnagar M. Asparagus racemosus (Shatavari):A versatile female tonic. Int J Pharm Biol Arch. 2011;2(3):855-63.

10. Ahmad S, Ahmed S, Jain PC. Chemical examination of Shatavari Asparagus racemosus.Bull Medico Ethano Bot Res.1991;12(3-4):157-60.

11. Goyal RK, Singh J, Lal H. Asparagus racemosus an update. Indian J Med Sci. 2003;57(9):408-14.

12. Kamat JP, Boloor KK, Devasagayam TP, Venkatachalam SR. Antioxidant properties of Asparagus racemosus against damage induced by gamma radiation on rat liver mitochondria. J Ethanopharmacol. 2000;71(3):425-35.

13. Handa SS, Suri OP, Gupta VN, Suri KA, Satti NK, Bhardwaj V. Oligospirostanoside from Asparagus racemosus as immunomodulator, US Patent No.6649745.2003.

14. Joshi T, Sah SP, Singh A. Antistress activity of ethanolic extract of Asparagus racemosus wild roots in mice. Indian J Exp Biol. 2012;50(6):419-24.

15. Singh GK, Garabadu D, Muruganandam AV, Joshi VK, Krishnamurthy S. Antidepressant activity of Asparagus racemosus in rodent models. Pharmacol Biochem Behav. 2009;91(3):283-290.

16. Wiboonpun N, Phuwapraisirisan P, Tippyang S. Identification of antioxidant compound from Asparagus racemosus. Phytother Res. 2004;8(9):7713.

17. Boger DL, Mitscher LA, Mullican MD, Drake SD, Kitos P. Antimicrobial and cytotoxic properties of 9,10 dihydrophenanthrene: Structure activity studies on juncusol. J Med Chem. 1985;28(10):1543-7.

18. Mandal SC, Nandy A, PalM, Saha BP. Evaluation of antibacterial activity of Asparagus racemosus wild root. Phytother Res. 2000;14(2):118-9.

19. Acharya SR, Acharya NS, Bhangale JO, Shah SK, Pandya SS. Antioxidant and hepatoprotective action of
Asparagus racemosus Wild root extracts. Indian J Exp Biol. 2012;50(11):795-801.

20. Joshi JDS. Chemistry of Ayurvedic crude drugs: Part VIII: Shatavari 2. Structure elucidation of bioactive shatavarin I and other glycosides. Indian J Chem Section B Organ Chem. 1988;27(1):12-6.

21. Byrne JA, Grieve DJ, Cave AC, Shah AM. Oxidative stress and heart failure. Arch Mal Coeur. 2003;96:21421.

22. Simunek T, Sterba M, Popelova O, Adamcova M, Hrdina R, Gersl V. Anthracycline induced cardiotoxicity: overview of studies examining the roles of oxidative stress and free cellular iron. Pharmacol Rep. 2009;61(1):154-71.

23. Puri A, Maulik SK, Ray R, Bhatnagar V. Electrocardiographic and biochemical evidence for the cardioprotective effect of vitamin $\mathrm{E}$ in doxorubicininduced acute cadiotoxicity in rats. Eur J Pediatr Surg. 2005;15(6):387-91.

24. Haed S, Barshack I, Luboshits G, Wexler D, Deutsch V, Keren G, et al. Erythropoietin improves myocardial performance in doxorubicin-induced Cardiomyopathy. Eur Heart J. 2006;27(15):1876-83.

25. Akinmoladun AC, Ibukun EO, Afor E, Akinrinlola BL, Onibon TR, Akinboboye AO, et al. Chemical constituents and antioxidant activity of Alstonia boonei. Afr J Biotechnol. 2007;6(10):1197-201.

26. Guleria S, Tiku AK, Singh G, Koul A, Gupta S, Rana S. In vitro antioxidant activity and phenolic contents in methanol extracts from medicinal plants. Journal of plant biochemistry and biotechnology. 2013 Jan 1;22(1):9-15.

27. Suchalatha S, Devi SCS. Protective effect of Terminalia chebula against experimental myocardial injury induced by isoproterenol. Indian Biol. 2004;42(2):174-8.

28. Panda VS, Naik SR. Cardioprotective activity of ginkgo bilobaphytosomes in isoproterenol induced myocardial necrosis in rats: a biochemical and histoarchitectural evaluation. Exp Toxicol Pathol. 2008;60(4-5):397-404.

29. Saad SY, Najjar TA, AI-Rikabi AC. The preventive role of desferoxamine against acute doxorubicininduced cardiac, renal and hepatic toxicity in rats. Pharmacol Res. 2001;43(3):211-8.

30. Roy RN, Bhagwager S, Chavan SR, Dutta NK. Preliminary pharmacological studies on extracts of root of Asparagus racemosus (Satavari), Willd, Lilliaceae. J Res Indian Med. 1971;6:132-8.

31. Premanath R, Lakshmidevi N. Studies on antioxidant activities of Tinospora cordifolia leaves using in vitro models. J Am Sci. 2010;6(10):736-42.

Cite this article as: Vishwakarma $\mathrm{P}$, Chatterjee $\mathrm{M}$, Sharma M, Saini M, Goel R, Saxena KK. Evaluate the creatinine clearance and compare nephrotoxic potential of amikacin and Gentamicin, in postoperative patients with normal baseline renal function. Int J Basic Clin Pharmacol 2019;8:1693-9. 